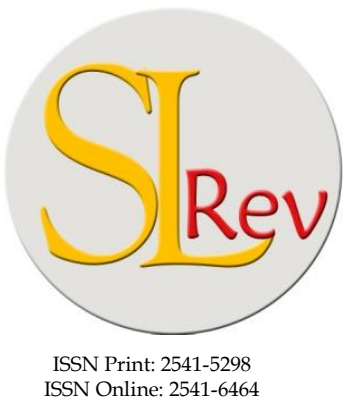

\section{Potential Investor Claims and Possible State Defenses During the Covid-19 Emergency}

Jalan Srijaya Negara, Palembang, South Sumatra 30139, Indonesia.

Phone: +62711-580063Fax: +62711-581179

E-mail: sriwijayalawreview@unsri.ac.id| sriwijayalawreview@gmail.com

Website: http://journal.fh.unsri.ac.id/index.php/sriwijayalawreview

\author{
Sefriani, ${ }^{a^{*}}$ and Seguito Monteiro ${ }^{\mathrm{b}}$ \\ $a^{*}$ Corresponding Author. Faculty of Law, Islamic University of Indonesia, Yogyakarta, Indonesia. E-mail: sefria- \\ ni@uii.ac.id \\ b Faculty of Law, Universidade Dili, Dili, Timor Leste. Email: s.monteiro_1981@yahoo.com
}

\begin{tabular}{|c|c|}
\hline Article & stract \\
\hline 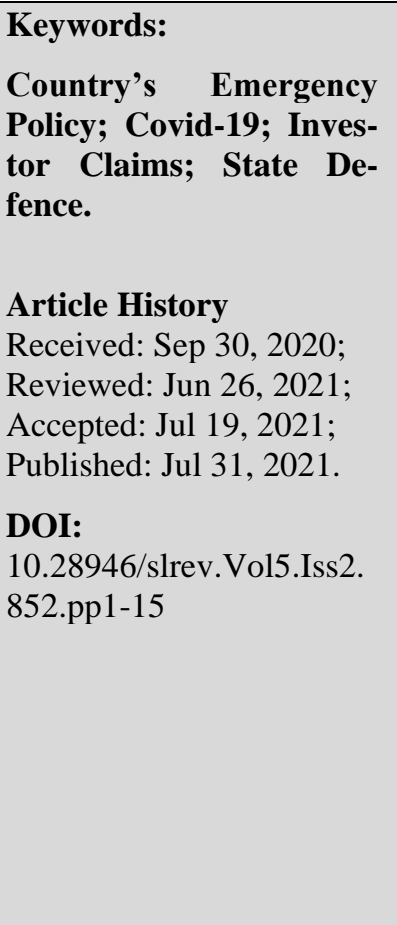 & $\begin{array}{l}\text { Since it was announced as a public health emergency of international con- } \\
\text { cern in } 2019 \text {, Covid-19 has caused enormous loss of property and life. The } \\
\text { country's emergency policies in responding to the Covid outbreak are nu- } \\
\text { merous, such as closing public transportation and prohibiting the export of } \\
\text { medical devices. These policies have potentially harmed the interests of in- } \\
\text { vestors. This study has three purposes: investors' potential claims to chal- } \\
\text { lenge state measures addressed to Covid-19, the legal defences of states, and } \\
\text { the possibility of an international investment dispute. This study shows that } \\
\text { investors' potential claims may be delivered based on violations of the prin- } \\
\text { ciples of fair and equal treatment, full protection and security, and national } \\
\text { treatment and the most favoured nations. While a state can defend itself } \\
\text { based on the principles of force majeure and state necessity, states can also } \\
\text { defence through Non preclude measures or right to regulate clause in inter- } \\
\text { national investment agreements. In addition, it would also be better to build } \\
\text { international solidarity and cooperation to mitigate and defeat the Covid-19 } \\
\text { pandemic than sue the government before ISDS. States need collective ac- } \\
\text { tion to avoid a surge of investor-state Arbitration. Governments' policy to } \\
\text { combat Covid-19 is to be considered as acting in necessity and therefore } \\
\text { cannot be found in breach of their investment treaty obligations as long as } \\
\text { that policy meet the necessity, proportionate, and non-discrimination re- } \\
\text { quirements. }\end{array}$ \\
\hline \multicolumn{2}{|c|}{$\begin{array}{l}\text { (C2021; This is an Open Access Research distributed under the term of the Creative Commons Attribution License } \\
\text { (https://Creativecommons.org/licences/by/4.0), which permits unrestricted use, distribution, and reproduction in } \\
\text { any medium, provided the original works is properly cited. }\end{array}$} \\
\hline
\end{tabular}

\title{
INTRODUCTION
}

Globalization and the outbreak of disease have made public health an international concern. There were some examples of situations of transboundary health emergencies, as demonstrated by the Severe Acute Respiratory Syndrome (SARS) and Ebola epidemics, the cholera outbreak 
in post-earthquake Haiti, the outbreaks of H1N1 and H3N2 influenza, ${ }^{1}$ and more recently is the pandemic of the Corona Virus Disease 2019 or Covid-19, which has spread rapidly worldwide.

Covid-19 has implications not only for the health and safety of the community but also for society's social, economic, and welfare aspects. Almost all states under their national law are taking drastic, wide-ranging measures to limit the spread of the Covid-19 virus. Russia, Vietnam, Kazakhstan, and Cambodia imposing export bans on wheat, rice, wheat flour, buckwheat, sugar, and sunflower oil, to ensure domestic food security. While Canada, Ecuador, and Germany have issued compulsory licenses on patented drugs and devices, the Spanish government intervene and temporarily occupy industries, factories, including private health companies, in the pharmaceutical sector; private hospitals to ensure the supply of goods and services necessary for the protection of public health. ${ }^{2}$ In Europe, states have requisitioned private supplies of masks and other protective equipment for use in state-run hospitals. Similarly, China has also seized private hotels and hospitals to house patients. Furthermore, the Italian government banned the export of ventilators. ${ }^{3}$ The Indonesian government issued Minister of Health Regulation No. 9 of 2020 concerning Large-Scale Social Limitation to overcome the spread of Covid-19. The Indonesian government has restricted activities at schools, workplaces, places of worship; public facilities, stopped public transportation, and closed non-essential businesses.

These state measures addressed Covid-19's potentially adverse effect on private investments in almost all business sectors, may dramatically decrease sales revenues even for in-demand products. ${ }^{4}$ The tourism and transportation industries were the first victims of such restrictions. The state is measuring to prohibit the export of some commodities having a broader impact on the global economy and on supply chains and other transnational commercial relations. ${ }^{5}$ The State measures to overcome Covid-19 that are detrimental to investors as described above, potentially cause lawsuits from investors. They can sue through the investor-state dispute settlement (ISDS). Therefore, the actions taken by the state must be appropriate, based on state necessity, non-discriminatory and proportional. ${ }^{6}$

There are three legal issues analysed in this paper: investors' potential claims challenging state measures on Covid-19. Secondly is the legal defences which the state could use to justified measures addressing Covid-19, and thirdly what should be done internationally concerning the possibility of international investment dispute concerning state measures response Covid-19 pandemic. This paper consists of five parts: introduction, potential claims by the foreign inves-

1 Chiara Giorgetti, "International Health Emergencies in Failed and Failing States," Georgetown Journal of International Law 44 (2013): 1347.

2 Oliver Hails, "Epidemic Sovereignty? Contesting Investment Treaty Claims Arising from Coronavirus Measures," 2020, 1-5. https://www.ejiltalk.org/epidemic-sovereignty-contesting-investment-treaty-claimsarising-from-coronavirus-measures/, last viewed January 2021

3 Hogan Lovells, "Covid-19: Will State Measures Give Rise to a New Set of Investment Claims ?," Hogan Lovells, 2020, https://www.hoganlovells.com/ /media/hogan-lovells/pdf/2020-pdfs/2020_04_02_Covid19-andinvestment-arbitration.pdf?la=en.

4 Marie Sutton, "Forced Quarantine \& Isolation: Does the Law Adequately Balance Individual Rights and Societal Protection," U. La Verne L. Rev. 39 (2017): 98.

5 Federica Paddeu and Freya Jephcott, "Covid-19 and Defences in the Law of State Responsibility: Part II," no. March (2020): 1-5. https://www.ejiltalk.org/covid-19-and-defences-in-the-law-of-state-responsibility-part-ii/, last viewed January 2021

6 Fazal R Khan, "Ensuring Government Accountability during Public Health Emergencies," Harvard Law \& Policy Review 4, no. 2 (2010): 319-38. 
tor, Possible State defence in the Covid emergency, and the need for collective action to avoid a surge of investor-State Arbitration, and conclusion.

\section{RESEARCH METHOD}

The research method used in this article is normative juridical. While the research data used is secondary data consisting of primary legal materials such as the international investment agreement and Draft Articles on Responsibility of States for Internationally Wrongful Acts with commentaries 2001 (ARSIWA). The secondary legal materials include many articles from reputable international journals and nationally accredited journals relevant to the issues raised. The approach method used is a conceptual, historical and comparative approach. The analytical method used is descriptive-analytical.

\section{ANALYSIS AND DISCUSSION Potential Claims by Foreign Investors}

State measures to respond to the Covid-19 pandemic impact many contracts of private parties and may affect any obligations of the state, governed by public international law. The state can be sued for breach of the substantive provisions of International Investment Agreements (IIAs) on violations of the Fair and Equal Treatment (FET) standard, complete protection and security, expropriation, and non-discrimination. ${ }^{7}$

The FET standard is one of the most invoked substantive standards in ISDS and encompasses both procedural and substantive elements. Some elements of the FET are legitimate expectations, due process, denial of justice, the rule of law, non-discrimination, transparency, consistency, good faith, and reasonableness. ${ }^{8}$ The FET standard prohibits arbitrary measures reflecting disregard of due process of law or unreasonable or excessive considering the circumstances. In evaluating claims, tribunals will generally consider whether the effects of the State measure remain proportionate concerning the affected rights and interests. State responses downplaying the risks of Covid-19 and subsequently reversing course and imposing drastic measures could violate the FET standard.

Under non-discrimination clauses, states must treat foreign investors favourably as local investors or as favourably as any foreign investors from other countries. Consequently, State measures that are not compatible with non-discrimination principles violate FET standards. The investor can also claim under violation of the expropriation clause. The suspension of an export license for several months and investor's loss of control of the property for one year, ${ }^{9}$ The seizure of a private company that produces medical equipment, taking control of private hospitals and clinics involuntary without adequate compensation, Border closures or lockdown orders, results in the investment shutting down permanently can constitute indirect expropriation. Most treaties require any expropriation to be done with a public purpose, under due process and to be

Charles Chernor Jalloh, "ICSID Annulment-U.S.-Argentina Bilateral Investment Treaty-ILC Articles on State Responsibility-Necessity- Essential Interests-Lawful Measures during Economic Crises,” The American Journal of International Law, n.d., 548.

8 Katia Yannaca-Small, "Fair and Equitable Treatment Standard: Recent Developments," Standards of Investment Protection 7, no. 1 (2012), https://doi.org/10.1093/acprof:oso/9780199547432.003.0006.

9 William W. Burke-White and Andreas Von Staden, "Investment Protection in Extraordinary Times: The Interpretation and Application of Non-Precluded Measures Provisions in Bilateral Investment Treaties," Virginia Journal of International Law 48, no. 2 (2008): 310. 
accompanied by adequate compensation. Government seizures of private property or other acts affecting an investment may give rise to claims of unlawful expropriation if it is not accompanied by adequate compensation.

\section{Possible State Defence in Covid Emergency}

Two kinds of State defence can be delivered against possible foreign investor claims due to its policy against Covid-19. ${ }^{10}$ The first defence is by the International investment treaty (IIA), while the second defence is by international customary law (ICL). The International Court of Justice (ICJ) in the Nicaragua case distinguishes these two sources of law even though their contents are identical and even though states are bound to the two sources of law. The two sources of law remain separate from each other. ${ }^{11}$

\section{State Defence under IIAs}

The Non-Precluded Measures (NPM) clause is an example of an exclusion clause found in investment treaties. NPM clause is the exclusion of pacta sunt servanda principle ${ }^{12}$ NPM clause will grant state flexibility to protect its public interests in exceptional circumstances. The existence of the NPM clause in the IIAs is an expression of the right of the state to regulate. A state's authority to make rules in its territory is a fundamental embodiment of state sovereignty. This clause can free the state from liability claims related to policy changes that are not following the investment treaty when the policy is considered very important to protect the fundamental public interests. ${ }^{13}$ If the exception applies, the treaty does not apply to the disputed measure. However, all will depend on the particular treaty, not all investment treaty contains NPM clause.

NPM Clause carries out the functions of risk allocation, like transferring the cost of investment losses from the host state to investors in exceptional circumstances, as in the case of Argentina's financial crisis. NPM clause transfers risks to investors, and the state is not responsible for actions taken, which in normal conditions are in fact a violation of the investment treaty. NPM clause makes such protection in exceptional situations or crises invalid. ${ }^{14}$ The scope of NPM clauses in various investment treaties includes the following aspects: security, international peace and security, public order, public health, also public morality. ${ }^{15}$

NPM clause is generally articulated as an exception to the investment treaty substantive provisions and not merely a justification or a reason for violations. NPM clause is made an exception by using the phrase "shall not preclude the applicability of measures" or "shall not apply to". ${ }^{16}$ More recent investment treaties have more robust specific NPM clauses, which explicitly

10 Paddeu and Jephcott, "Covid-19 and Defences in the Law of State Responsibility: Part II," 2020., https://www.ejiltalk.org/covid-19-and-defences-in-the-law-of-state-responsibility-part-ii/, last viewed January 2021

11 Burke-White and Staden, "Investment Protection in Extraordinary Times: The Interpretation and Application of Non-Precluded Measures Provisions in Bilateral Investment Treaties."

12 Stefan Ditrih, Svetlana Marković, and Olgica Milošević, "Change of Circumstances and Force Majeure Clauses in Serbian Legal System and Sources of International Uniform Law," Economic Themes 57, no. 1 (2020): 67-86, https://doi.org/10.2478/ethemes-2019-0005.

13 Sefriani, "The Urgency of Non-Precluded Measures Clause in Indonesian Bilateral Investment Treaty," Padjadjaran Journal of Law 6, no. 2 (2019): 233-53.

14 Burke-White and Staden, "Investment Protection in Extraordinary Times: The Interpretation and Application of Non-Precluded Measures Provisions in Bilateral Investment Treaties."

15 Burke-White and Staden.

16 Sefriani, "The Urgency of Non-Precluded Measures Clause in Indonesian Bilateral Investment Treaty." 
exclude non-discriminatory regulatory measures for lawful public interest objectives, including public health, from FET or indirect expropriation obligations. This clause may protect States against FET or indirect expropriation claims by the foreign investor. The existence of the NPM clause in the investment treaty may insulate Covid-19 measures from investment treaty claims.

BIT between Indonesia and the United Arab Emirates, signed on July 24, 2019, has no NPM clause but the right to regulate clause. Article 14, paragraph 1 of this BIT stipulated, "nothing in this agreement shall be construed to prevent a contracting party from adopting, maintaining or enforcing any measures otherwise consistent with this agreement that is considered appropriate to protect the environment, human or plant life or health." Some business activities limitations imposed by the Indonesian government to overcome the spread of Covid-19 and possibly harming investors may be protected by this provision as long as such measures are not applied arbitrarily or unjustifiably or do not constitute disguised restrictions of investments the other contracting party.

\section{State Defence under ICL}

The second defence that the host state can apply against foreign investors' claims concerning its policies to overcome the spread of Covid-19 is through international customary law (ICL) that codified in ILC draft Articles on the Responsibility of States for Internationally Wrongful Acts (ARSIWA).

First and foremost, under ICL, all States have an obligation to ensure that aliens are treated following the minimum standard of treatment. Any treatment that falls short of this level is wrongfulness of the state and gives rise to liability on the part of the minimum standard of treatment. ${ }^{17}$ State defence to preclude a state could apply the wrongfulness of an act of the State under ARSIWA in the absence of an exception clause in the IIA. Those State defences consist of Force Majeure, necessity, and distress are doctrines found in public international law which operate to preclude the legal wrongfulness of an act.

\section{Force majeure (FM) doctrine}

To mitigate the effect of businesses outbreak, some states have declared states of emergency under their domestic laws. On January 30 2020, the China Council for Promotion of International Trade (CCPIT) issued FM certificates to exempt their enterprises from the obligation to fulfil contractual agreements with overseas buyers. ${ }^{18}$ They desire FM certificates can protect them from breach of contract claims. ${ }^{19}$ As of March 3, 2020, China had issued 4,811 FM certificates to limit the liability of Chinese businesses unable to meet their contractual obligations. France and India are considering similar measures to shield their businesses from the impact of the Covid-19 emergency. ${ }^{20}$

17 Doug Jones, "Student Advocate Committee Investor-State Arbitration in Times of Crisis Author ( s ): Doug Jones Source: National Law School of India Review, Vol . 25 , No . 1 ( 2013 ), Pp . 27-61 Published by: Student Advocate Committee Stable URL : Https:/Www.Jsto" 25, no. 1 (2020): 27-61.

18 Natalie Caton, "Coronavirus Covid-19: The Legal Impact on Force Majeure Events ( Australia )," DLA paper, February 12 2020. https://www.dlapiper.com/uk/global/insights/publications/2020/02/coronavirus-covid19-thelegal-impact-on-force-majeure-events/, last viewed March 2020

19 HRW, “Coronavirus: Can It Be A Force Majeure Event?," 2020. https://www.hfw.com/Coronavirus-Can-it-be-aForce-Majeure-event-Feb-2020, last viewed January 2021

20 Federica Paddeu and Freya Jephcott, "Covid-19 and Defences in the Law of State Responsibility: Part II," . https://www.ejiltalk.org/covid-19-and-defences-in-the-law-of-state-responsibility-part-ii/ last viewed July 2020 
On the other side, the Indonesian government does has not issued FM certificates. Indonesia only issued Presidential Decree Number 12 of 2020 concerning Determination of Non-natural Disasters Spreading Corona Virus Disease 2019 (Covid-19) as a national disaster. The problem is whether the China FM certificates or the Indonesian presidential decree can be used as legal bases for defence from claiming liability for their failure to perform their contractual obligations due to the Covid pandemic 19.

Force majeure goes by many other terms, such as fortuitous events, impossibility, acts of God, unavoidable necessity, physical necessity, frustration, and impracticability. ${ }^{21}$ Force majeure is invoked in the context of alleged irresistible or unforeseen or unforeseeable, or uncontrollable supervening events that the defendant could neither have prevented nor controlled. ${ }^{22}$ The state has been compelled to act incompatible with its international obligation because of an unforeseen event beyond the control of the state. The events are included hurricanes, earthquakes; drought; tsunami; heavy rain, windstorms, blizzards, and floods. ${ }^{23}$

Force majeure stipulated in article 23 ARSIWA. This provision mentioned that A successful claim of FM should fulfil five conditions: i) there must be an unforeseen event or an irresistible force; ii) the event or force must be beyond the control of the state; iii) the event must make it 'materially' impossible to perform an obligation; iv) the state must not have contributed to the situation; and v) the state must not have assumed the risk of the situation occurring.

Force majeure does not apply if the situation of force majeure is due to the conduct of the state invoking it or the state has assumed the risk of that situation occurring, either alone or in combination with other factors.

Commentaries on ILC Draft ARSIWA 2001 mentioned that: “...[u]nforeseen means that the event must have been neither foreseen nor of an easily foreseeable kind. While Irresistible force emphasizes that there must be a constraint which the state was unable to avoid or oppose by its own means...." Concerning Covid 19, the facts have shown that no state could have prevented Covid 19 from reaching their territories. Border closures and airport screenings have proven ineffective in preventing the reach of the Covid $19 .{ }^{24}$

Impossibility must be material and absolute. The material should be a physical inability to perform the obligation. 'Absolute required no other better way provided other than measure has been taken to perform the obligation in question. It is confirmed by the rationale of the plea, which according to the Commentary, lays in the fact that the non-performance of the obligation is 'involuntary or involves no element of free choice.' 25

Concerning the outbreak of Covid-19, it is not easy for a state to prove the material impossibility of its performance. It depends on the specific obligation stipulated in the treaty also the

21 Myanna Dellinger, "Rethinking Force Majeure in Public International Law," Pace Law Review 37, no. 2 (2017): 455.

22 Michael Polkinghorne and Charles B. Rosenberg, "The Ebola Epidemic and Force Majeure: Expecting the Unexpected," Alternatives to the High Cost of Litigation 32, no. 11 (2014): 165-78, https://doi.org/10.1002/alt.21557.

23 Dellinger, "Rethinking Force Majeure in Public International Law."

24 Yannaca-Small, "Fair and Equitable Treatment Standard: Recent Developments."

25 Gregory C. Buffalow, "The Force Majeure Defense - Recent Cases, Boilerplate and Analysis," Journal of Maritime Law and Commerce 42, no. 2 (2011): 211-30. 
particular circumstances in each case. However, in most cases, even if complex, States still has a choice to the respect compliance. ${ }^{26}$

\section{State Necessity doctrine}

Necessity has been invoked frequently by states facing economic and financial crises. Necessity is also applied in some other cases. Under ICL, Necessity defence has been successfully invoked in some cases in the Caroline case, the Fisheries Jurisdiction and Russian Fur Seals cases, the Torrey Canyon case, Anglo-Portuguese dispute 1832, also the series of cases regarding obligations to repay external debt in times of economic crisis. ${ }^{27}$

As reflected in the ILC Articles and its commentaries, international customary law does not offer a definitive answer to the question in order for a state to invoke necessity successfully. In practice, the tribunals have applied the required elements of necessity inconsistently, and some uncertainty persists. In particular, necessity has often been considered alongside national and essential security clauses, whose operation may deny any award of compensation for the damages suffered during the recognized period of necessity. However, after the end of the period of necessity, a state may no longer be exempted from the requirement to pay compensation. ${ }^{28}$

The doctrine of necessity allows governments to breach their treaty commitments under certain mitigating circumstances. ${ }^{29}$ There are four elements of the state of necessity mentioned by the Russian government in the case of a ban on seal hunting to England: 1) the exceptional nature of the situation; 2) the imminent character of the threat against a vital State interest; 3) the impossibility of avoiding the risk by other means; and 4) the necessarily temporary nature of this justification, linked to the due danger's persistence. ${ }^{30}$

Finally, the state necessity defence was applied to denote exceptional cases where state action is the only method that can be used to safeguard essential interests threatened by a grave and imminent peril, for the time being, not intended to perform international obligations with worse quality. Furthermore, the necessity defence is only a mitigant rather than a defence. It is an exception from illegality and, in some instances, an exception from responsibility. ${ }^{31}$

The state Necessity defence has been acknowledged in several ICL decisions and is now stipulated in article 25 ARSIWA as follow: ${ }^{32}$

"A State may not invoke necessity as a ground for precluding the wrongfulness of an act not in conformity with an international obligation of that state unless the act: 1) Is the only way for the state to safeguard an essential interest against a grave and imminent peril; 2) Does not seriously impair an essential interest of the State or States towards which the obligation exists, or of the international community as a whole. In any case, necessity may not be invoked by a State as a ground for precluding wrongfulness if: a) The international obligation in question excludes the possibility of invoking necessity, or b) The State has contributed to the situation of necessity."

26 Yannaca-Small, "Fair and Equitable Treatment Standard: Recent Developments."

27 Andreas Burke-White, William W.; Von Staden, "Investment Protection in Extraordinary Times: The Interpretation and Application of Non-Precluded Measures Provisions in Bilateral Investment Treaties," Virginia Journal of International Law 48, no. 2 (2008): 309-410.

28 Burke-White, William W.; Von Staden.

29 Robert Martinson, "Is This Really Necessary: The Scope of the Doctrine of Necessity in 21st Century Investment Treaties," Creighton International \& Comparative Law Journal 9, no. 1 (2017): 1-28.

30 Martinson.Martinson.

31 ICSID, Continental Casualty Co. v. the Argentine Republic, ICSID Case No. ARB/03/9, Award, 160 (September 5, 2008) (2008).

32 Alan O Sykes, "Economic 'Necessity' In International Law," American Journal of International Law 109 (2015): 1-25. 
Article 25 ARSIWA describes the doctrine of state necessity in very restrictive terms. State necessity defence will be successful if it fulfils the following requirements: 1) there must be a grave and imminent peril; 2) this peril must threaten a vital interest; 3) the state's actions must not seriously impair another vital interest; 4) the state's act was the only way to safeguard the interest from that peril. State necessity defence will be ignored if: a) the obligation in question excludes reliance on necessity; b) the state contributed to the situation of necessity.

State necessity is different from force majeure. In state-necessity, the state has a choice not to take actions that can harm the interests of other countries. The state has the capability to choose some other course of conduct. However, what was chosen by the respondent state is the best choice to prevent the more significant threat. If there are other alternatives with less adverse impact on the plaintiff, state necessity defence could not be accepted, while force majeure situations contain superior force. ${ }^{33}$

Vital interest, imminent, and the only way, are the main element of necessity. In the Gabcikovo-Nagymaros case, ICJ concluded as follows:

"...the state of necessity is a ground recognized by customary international law. This can only be accepted on an exceptional basis, under certain strictly defined circumstances that must be cumulatively satisfied. The state concerned is not the sole judge of whether those circumstances have been met. ${ }^{34}$ Element of grave and imminent peril will be founded appropriately in Covid 19 outbreak. Covid 19 outbreak poses an imminent threat of grave harm to the world's population.; Thousands of people have died since this case emerged at the end of 2019, and there is no sign that the Covid 19 will end, which means that the Covid 19 is still become threatening the safety of all citizens of the world."

Furthermore, in the case of $L G \& E v$. the Argentine Republic before ICSID, the tribunal stipulated that the economic crisis threat Argentina's vital interests. Argentina's economic crisis is a severe threat to its existence, its political and economic survival, the possibility of maintaining its essential services in operation and preserving its internal peace. The tribunal also mentioned that Argentina did not contribute substantially to the creation of the crisis. There was "no serious evidence in the record prove that the government contributed to that economic crisis. ${ }^{35}$ Requirements of essential interest were founded in the Covid 19 case since the outbreak of Covid-19 threatened the health and safety of people around the world.

The state's act needed not to impair another vital interest seriously; Quarantine policies, lockdowns, large-scale restrictions limiting the space for investors and delaying their costly projects are detrimental to investors, such as the export ban on medical devices. However, this policy is essential to protect the interests of citizens in the country or at home. The WHO has even recommended this policy. The investment losses of the home state are not as severe as the losses of the host country. Like the statutory restrictions, the export ban was not implemented. It may also be added that the measures do not seriously impair the interests protected by these rights since they are only temporary measures, and these are rights that are subject to derogation in most human rights systems. ${ }^{36}$

Moreover, action taken by a state should be the only way to protect the vital interests and losses that will arise when the state takes action on behalf of the state necessity doctrine. If there

33 Sykes.

34 Sykes.

35 Martinson, "Is This Really Necessary: The Scope of the Doctrine of Necessity in 21st Century Investment Treaties.”, 9 Creighton Int'l \& Comp. L.J. 1 ,2017,1-28

36 Martinson. 
are other legitimate ways, even if they are high-cost or inconvenient, the plea on behalf of state necessity will be failed. The assessment must begin when the first step of policy in question was adopted, based on the degree of knowledge of state organs available to them at that time. It is crucial not to permit hindsight biases, which are likely to arise once we know what measures were effective. ${ }^{37}$

\section{Collective Action to Avoid a Surge of Investor-State Arbitration ${ }^{38}$}

On April 2, 2020, the UN General Assembly unanimously approved a resolution: Global solidarity to fight Covid-19, recognizing "the unprecedented effects" of the Covid 19 outbreak and calling for "intensified international cooperation to contain, mitigate, and defeat" the Covid-19 disease. It is the first intergovernmental statement from the UN on Covid-19, but it certainly will not be the last. This resolution showed that the UN call to face a global challenge with a truly united response. UN members record their conviction that the unprecedented crisis caused by the Covid-19 pandemic could be mitigated and successfully reversed through leadership and sustained global cooperation. In line with this resolution, states should come together and recognize the potentially overwhelming impacts of a surge of investment arbitration led by foreign companies, shareholders, portfolio investors, and bondholders against cash-strapped governments. In these times of turmoil, governments may not have the capacity to handle multiple claims or pay large amounts in compensation. This humanitarian crisis has proven to be a monumental national challenge for every government to reallocate resources and reformulate priorities. A coordinated response and solidarity will protect the country against lawsuits from investors.

States have taken very different measures impacting investments within their territory, all of which they will undoubtedly claim is necessary and justified. It cannot be denied that these are indeed exceptional times, as investors have also acknowledged. However, the defences listed above would not necessarily cover every measure a State might take, and there may well be grey areas linked to the breadth and significance of measures, the timing of their application, and aspects of potential compensation. For states to avoid liability for measures adopted in response to the Covid-19 pandemic, it will likely be crucial to be transparent about the scope and purpose of their measures, to observe applicable local laws and fundamental principles of due processes, such as non-retroactivity, as well as to ensure proportionality and measures which do not favour or discriminate against investors based on their nationality. Legitimate claims under investment treaties may well arise, and both States and investors would be well advised to be aware of their rights where such sensitive and complex issues are concerned.

States may jointly suspend the application of investor-state Arbitration concerning Covidrelated measures. They could also issue a joint declaration mentioned that the government's policy to combat Covid-19 is considered acting in necessity and therefore cannot be found in breach of their investment treaty obligations. This kind of declaration could become a consideration for investors seeking to Covid-19 measures or give guidance to the court when assessing states' defences.

37 Paddeu \& Jephcott, 2020

38 Nathalie Bernasconi-osterwalder, "Protecting Against Investor - State Claims Amidst COVID-19: A Call to Action for Governments," 2020, 1-10. https://www.iisd.org/system/files/publications/investor-state-claimscovid-19.pdf, last viewed December 2019 
Nonetheless, all concerns about the possibility of intentionally wrongful state actions disguised as Covid related measures could be addressed in the dispute resolution mechanisms stipulated in almost all investment treaties. ${ }^{39}$ Experts have called for a permanent restriction on ISDS claims against government measures targeting the health, economic and social effects of the Covid-19 pandemic. The United Nations Conference on Trade and Development (UNCTAD), too, is sounding alarm bells: "State measures to limit the adverse impact of the pandemic are manifold and vary from one country to another.

\section{CONCLUSION}

The Covid-19 outbreak caused casualties and resulted in enormous economic losses, especially for investors due to state policies to overcome Covid 19. Investors can deliver a claim before ISDS on behalf of violation of the Fair and equal treatment (FET) clause, complete protection and security, and non-discrimination clause. While The state can defend itself using exclusion clauses such as non-precluded measures generally found in international investment agreements or use arguments for the exclusion of responsibility known in the customary international law such as force majeure or state necessity. It is hoped that there will be collective action to avoid delivering the Covid-19 case before ISDS, which will very much cost and energy. It would be better directed to build international solidarity and cooperation against Covid-19 as confirmed in the UN General Assembly collaboration. Resolution concerning Global solidarity to fight Covid19, recognizing "the authentic effects" of the Covid-19 outbreak and calling for "intensified international cooperation to contain, mitigate, and defeat" the Covid-19 disease.

\section{REFERENCES}

Bernasconi-osterwalder, Nathalie. "Protecting Against Investor-State Claims Amidst COVID-19: A Call to Action for Governments," 2020, 1-10.

Buffalow, Gregory C. "The Force Majeure Defense - Recent Cases, Boilerplate and Analysis." Journal of Maritime Law and Commerce 42, no. 2 (2011): 211-30.

Burke-White, William W.; Von Staden, Andreas. "Investment Protection in Extraordinary Times: The Interpretation and Application of Non-Precluded Measures Provisions in Bilateral Investment Treaties." Virginia Journal of International Law 48, no. 2 (2008): 309410.

Caton, Natalie. "Coronavirus Covid-19: The Legal Impact on Force Majeure Events (Australia)," no. January (2020): 1-5.

Dellinger, Myanna. "Rethinking Force Majeure in Public International Law." Pace Law Review 37, no. 2 (2017): 455.

Ditrih, Stefan, Svetlana Marković, and Olgica Milošević. "Change of Circumstances and Force Majeure Clauses in Serbian Legal System and Sources of International Uniform Law." Economic Themes 57, no. 1 (2020): 67-86. https://doi.org/10.2478/ethemes-2019-0005.

Giorgetti, Chiara. "International Health Emergencies in Failed and Failing States." Georgetown Journal of International Law 44 (2013): 1347.

Hails, Oliver. "Epidemic Sovereignty? Contesting Investment Treaty Claims Arising from Coronavirus Measures," 2020, 1-5.

39 Bernasconi-osterwalder. 
HRW. "Coronavirus: Can It Be A Force Majeure Event?," 2020.

ICSID. Continental Casualty Co. v. the Argentine Republic, ICSID Case No. ARB/03/9, Award, 160 (September 5, 2008) (2008).

Jalloh, Charles Chernor. "ICSID Annulment-U.S.-Argentina Bilateral Investment Treaty-ILC Articles on State Responsibility-Necessity- Essential Interests-Lawful Measures during Economic Crises." The American Journal of International Law, n.d., 548.

Jones, Doug. "Student Advocate Committee Investor-State Arbitration in Times of Crisis Author ( s ): Doug Jones Source : National Law School of India Review, Vol . 25 , No . 1 ( 2013 ), Pp . 27-61 Published by: Student Advocate Committee Stable URL : Https://Www.Jsto" 25, no. 1 (2020): 27-61.

Khan, Fazal R. "Ensuring Government Accountability during Public Health Emergencies." Harvard Law \& Policy Review 4, no. 2 (2010): 319-38.

Lovells, Hogan. "Covid-19: Will State Measures Give Rise to a New Set of Investment Claims?" Hogan Lovells, 2020. https://www.hoganlovells.com/ /media/hoganlovells/pdf/2020-pdfs/2020_04_02_covid19-and-investment-arbitration.pdf?la=en.

Martinson, Robert. "Is This Really Necessary: The Scope of the Doctrine of Necessity in 21st Century Investment Treaties." Creighton International \& Comparative Law Journal 9, no. 1 (2017): 1-28.

Paddeu, Federica, and Freya Jephcott. "Covid-19 and Defences in the Law of State Responsibility: Part II,” no. March (2020): 1-5.

"Covid-19 and Defences in the Law of State Responsibility: Part II," no. iv (2020): 1-7.

Polkinghorne, Michael, and Charles B. Rosenberg. "The Ebola Epidemic and Force Majeure : Expecting the Unexpected." Alternatives to the High Cost of Litigation 32, no. 11 (2014): 165-78. https://doi.org/10.1002/alt.21557.

Sefriani. "The Urgency of Non-Precluded Measures Clause in Indonesian Bilateral Investment Treaty." Padjadjaran Journal of Law 6, no. 2 (2019): 233-53.

Sutton, Marie. "Forced Quarantine \& Isolation: Does the Law Adequately Balance Individual Rights and Societal Protection." U. La Verne L. Rev. 39 (2017): 98.

Sykes, Alan O. "Economic 'Necessity' In International Law." American Journal of International Law 109 (2015): 1-25.

Yannaca-Small, Katia. "Fair and Equitable Treatment Standard: Recent Developments." $\begin{array}{lllllll}\text { Standards of Investment Protection } & 7, & \text { no. } & 1 & \text { (2012). }\end{array}$ https://doi.org/10.1093/acprof:oso/9780199547432.003.0006. 